\title{
Chromosomal Variability in Akodon sp. (Rodentia, Cricetidae) ${ }^{1}$
}

\author{
Sanae Kasahara and Yatiyo Yonenaga-Yassuda \\ Departamento de Biologia, Instituto de Biociências, UNESP, Campus de Rio Claro, \\ CP 178, 13500, Rio Claro, SP, Brasil \\ and \\ Departamento de Biologia, Instituto de Biociências, \\ USP, CP 11461, 05421, São Paulo, SP, Brasil
}

Received April 3, 1980

In the genus Akodon approximately 15 South American species have been studied cytogenetically heretofore. Large variations in diploid numbers from $2 \mathrm{n}=14$ in $A$. arviculoides (Yonenaga 1972) to $2 \mathrm{n}=52$ in $A$. xanthorhinus (Bianchi et al. 1971) have been found. Furthermore, chromosome polymorphisms due to numerical and structural rearrangements both within the same population and among different populations have been described (Bianchi and Contreras 1967, Bianchi et al. 1973, Yonenaga et al. 1975, Yonenaga-Yassuda 1979).

Yonenaga et al. (1975) reported a case of interspecific hybridization between A. arviculoides $(2 \mathrm{n}=14)$ and Akodon sp. $(2 \mathrm{n}=24)$, two morphologically indistinguishable species. In the hybrids $(2 n=19)$, homology of $G$-band patterns of some chromosomes or chromosomal segments of these two species was established. Homology of several G-banded chromosomes from $A$. molinae $(2 \mathrm{n}=42)$, A. azarae $(2 \mathrm{n}=38)$ and $A$. obscurus $(2 \mathrm{n}=34)$ was also found (Bianchi et al. 1976).

Yonenaga et al. (1975) described the Q-band patterns of Akodon sp. and a variation in the chromosome number $(2 n=24,25)$ due to a supernumerary chromosome. A summary of cytogenetic data on two cases of mosaicism due to the presence of supernumeraries and $\mathrm{Y}$ chromosome elimination from somatic cells was presented by Yonenaga et al. (1976).

This paper presents additional data on the chromosomal variability in Akodon sp. as found in specimens collected from several regions in the state of São Paulo, Brazil.

\section{Material and methods}

The sample comprises 18 males and 12 females which were collected from Itapetininga, Iguape, Salesópolis, Guararema, Caçapava, Taubaté and São Paulo, in the state of São Paulo.

For chromosome analysis air-dried preparations of bone marrow, spleen, thyme and testis were made after "in vivo" colchicine $0.1 \%$ treatment $(1 \mathrm{ml}$ per $100 \mathrm{~g}$ of weight, for 2 hours); $0.075 \mathrm{M} \mathrm{KCl}$ was used as hypotonic solution for 15

1 Supported by grants from the Fundação de Amparo à Pesquisa do Estado de São Paulo (FAPESP), Programa Integrado de Genética (PIG), and the Conselho Nacional de Desenvolvimento Científico e Tecnológico (CNPq). 
minutes at $37^{\circ} \mathrm{C}$; the fixative was 3:1 methanol: acetic acid. Conventional staining was done with buffered Giemsa $2 \%, \mathrm{pH} 6.8$. G-bands were obtained by tripsin treatment (Seabright 1971) and C-bands, according to the method described by Sumner (1972).

\section{Results}

\section{Somatic chromosomes}

Fifteen males and 11 females had a $2 n=24$ karyotype which included 9 pairs of large and medium sized metacentrics and submetacentrics, 1 pair of small acrocentrics and 1 pair of minute metacentrics; the $\mathrm{X}$ chromosome was usually found

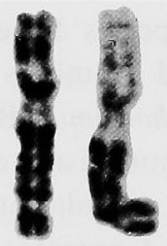

1

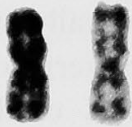

6

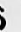

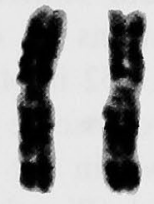

2

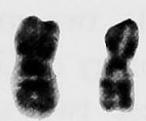

7

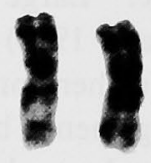

3

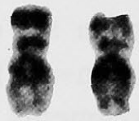

8

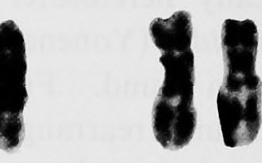

4

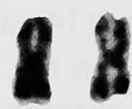

9

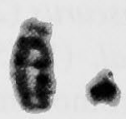

$X Y$

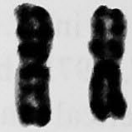

5

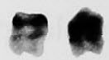

10

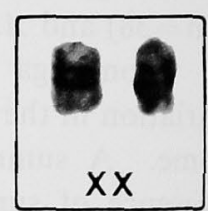

1

Fig. 1. G-banded karyotype of a male Akodon sp. $(2 \mathrm{n}=24)$, carrying the $\mathrm{X}$ marker. In the inset, the homomorphic sex pair of a female.

as a medium sized acrocentric and the $\mathrm{Y}$ chromosome was always a minute acrocentric. Six specimens (4 males and 2 females), however, showed a slightly different $X$ chromosome which had an enlarged short arm ( $X$ marker). No female was homozygote for this $\mathrm{X}$ marker. A G-banded karyotype of a male is presented in Fig. 1 .

One male and 1 female had a $2 n=25$ karyotype with a small extra submetacentric chromosome which was interpreted as a supernumerary. The female also had an $\mathrm{X}$ marker.

Two males showed mosaicism. One mosaic $(2 n=25 / 26)$ had one or two supernumerary chromosomes in bone marrow, spleen and thymic cells (Figs. 2a, 2b). The supernumerary appeared uniformally stained after G-banding. The frequencies of $2 n=25$ and $2 n=26$ cells were, respectively, $40 \%$ and $60 \%$, in 165 cells studied. 
The second case presented $2 n=23 / 24$ in spleen and bone marrow. The $2 n=24$ cells had a normal $X Y$ constitution while the $2 n=23$ cells lacked the $Y$ chromosome. The frequency of the XO and XY cells were about $80 \%$ and $20 \%$, respectively, in 60 cells studied. Both mosaics showed an acrocentric $\mathrm{X}$ without an enlarged short arm.

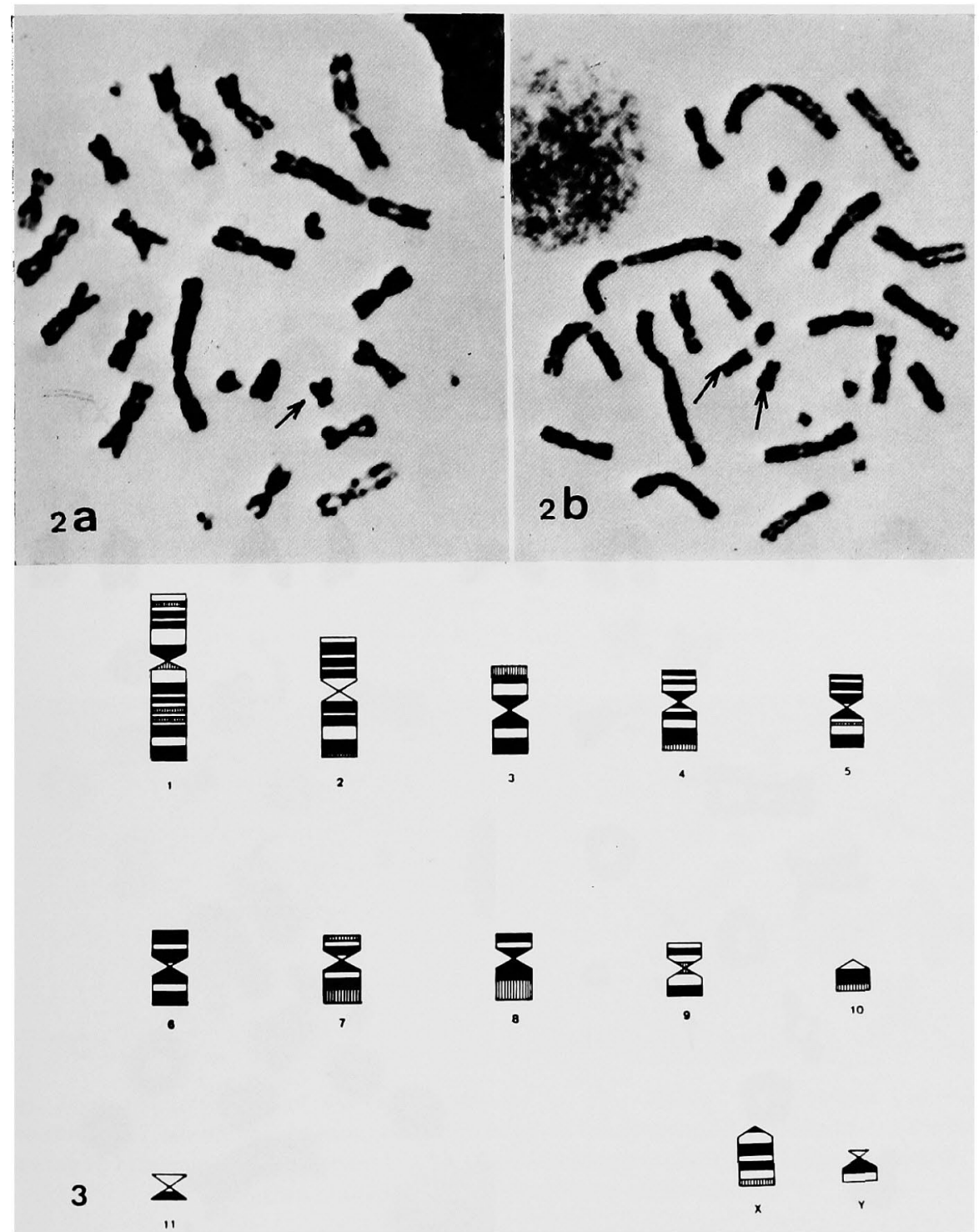

Figs. 2-3. 2a-b, G-banded metaphases of a male Akodon sp. with mosaicism. a, $2 \mathrm{n}=25$ cell. b, $2 n=26$ cell. Arrows indicate the supernumerary chromosomes. 3, G-banded diagram of metaphase chromosomes of Akodon sp.

The precise identification of all chromosomes in Akodon sp. could be made only in the banded karyotype (Fig. 1). A simplified diagram of the main G-band patterns of Akodon sp. chromosomes is shown in Fig. 3. 


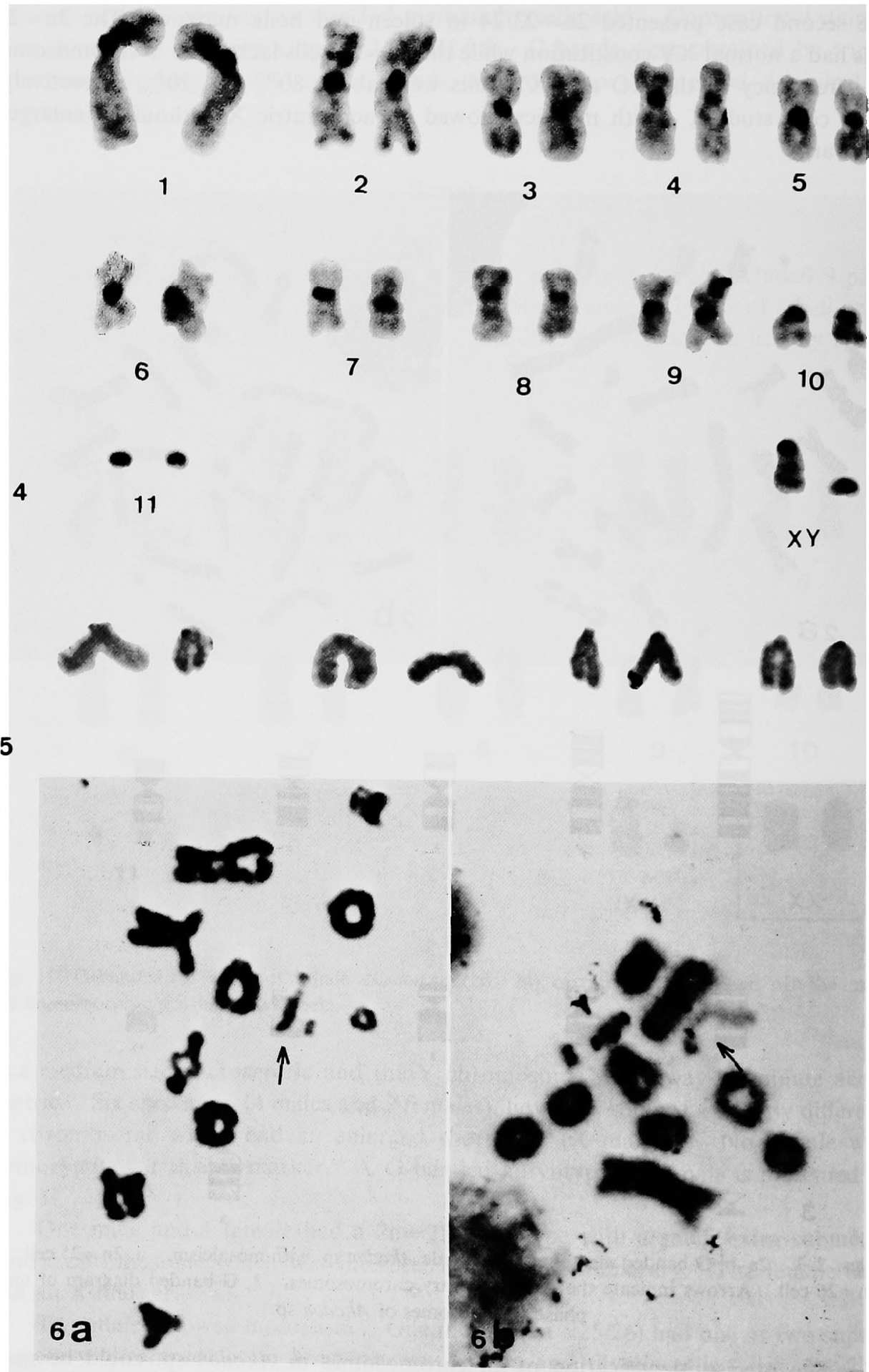

Figs. 4-6. 4, C-banded karyotype of a male Akodon sp. $(2 \mathrm{n}=24)$. The $\mathrm{X}$ chromosome is an acrocentric. 5, C-banded $\mathrm{X}$ chromosomes of a female Akodon sp., showing heteromorphism. 6a-b, $\mathrm{a}, \mathrm{G}-$ and $\mathrm{b}, \mathrm{C}$-banded meiotic chromosomes of a male Akodon sp. $(2 \mathrm{n}=24)$ showing 12 bivalents. The sex chromosome pair is indicated by an arrow. 
The C-band patterns of the somatic chromosomes are presented in Fig. 4. Constitutive heterochromatin was distributed at the pericentromeric regions of the autosomes and of the acrocentric $\mathrm{X}$ chromosome, and throughout the $\mathrm{Y}$. The $\mathrm{X}$ marker did not show any heterochromatin (Fig. 5). In some cells telomeric hetero-

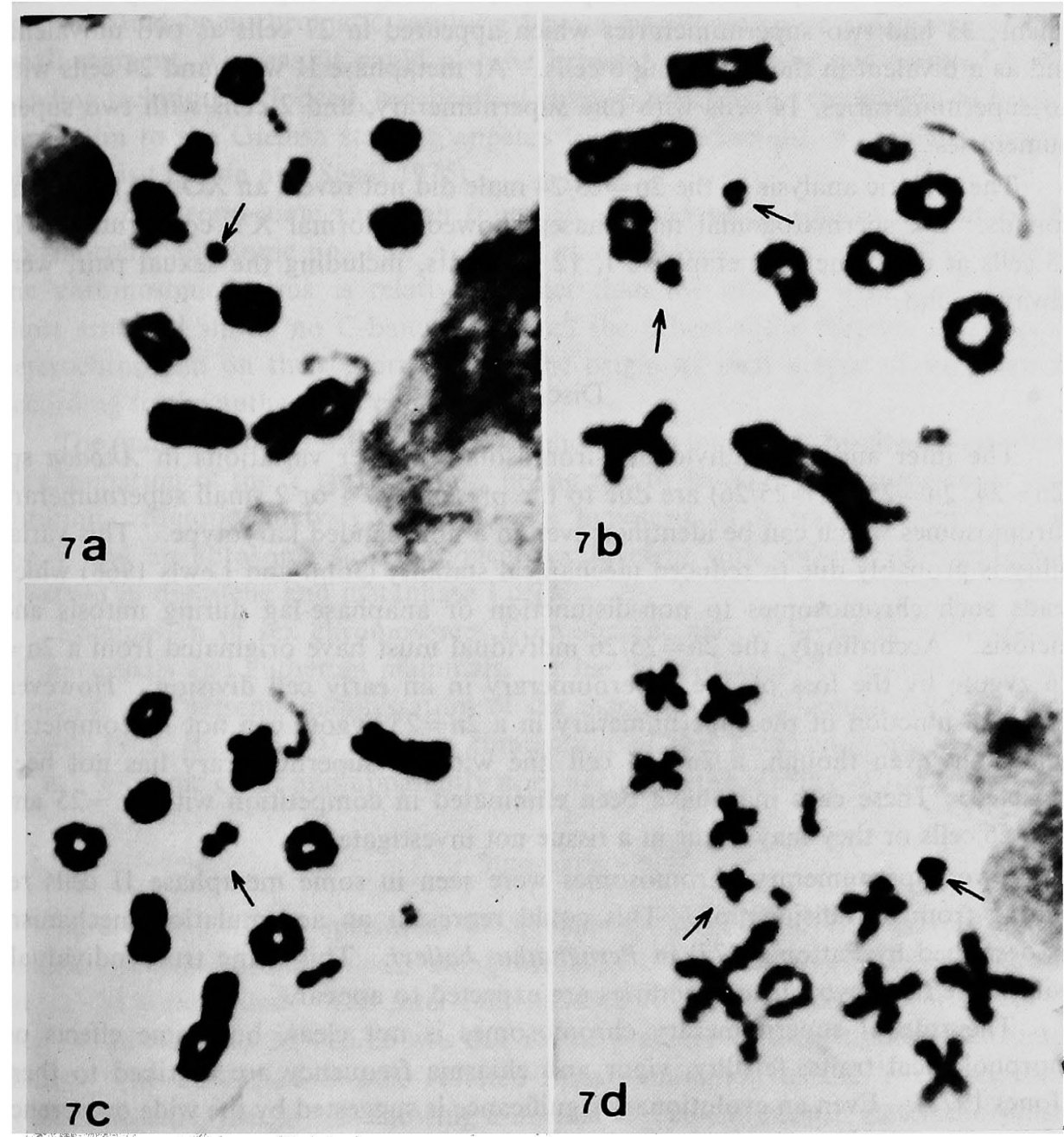

Figs. 7a-d. Meiotic cells of the mosaic Akodon sp. $(2 n=25 / 26)$, a, metaphase I showing 12 bivalents and 1 univalent. b, metaphase I showing 12 bivalents and 2 univalents. c, metaphase I showing 13 bivalents. d, metaphase II with 14 chromosomes including two supernumeraries. The arrows indicate the supernumerary chromosomes.

chromatin was noticed in pairs 2 and 10 and this was even more evident in meiotic cells (Fig. 6b).

\section{Meiotic chromosomes}

Meiotic analysis of $2 n=24$ males disclosed a condensed sex vesicle at pachytene, 12 bivalents at diplotene and metaphase I, and 12 dyads at metaphase II. Some 
meiotic preparations were treated for obtaining G- and C-bands (Figs. 6a, 6b). The bivalents 1 and 2 which could be well analysed showed the typical G-bands as presented by the corresponding somatic chromosomes.

The $2 n=25 / 26$ male also had two cell lines in the gonads (Fig. 7a, 7b, 7c, 7d). Among 68 cells at diplotene or metaphase I, 35 had one supernumerary as a univalent; 33 had two supernumeraries which appeared in 27 cells as two univalents and as a bivalent in the remaining 6 cells. At metaphase II we found 24 cells with no supernumeraries, 14 cells with one supernumerary, and 2 cells with two supernumeraries.

The meiotic analysis of the $2 n=23 / 24$ male did not reveal an XO cell line in the gonads. Six spermatogonial metaphases showed a normal XY constitution. In 25 cells at diplotene or metaphase I, 12 bivalents, including the sexual pair, were always found.

\section{Discussion}

The inter and intraindividual chromosome number variations in Akodon sp. $(2 n=24,2 n=25,2 n=25 / 26)$ are due to the presence of 1 or 2 small supernumerary chromosomes which can be identified even in a non-banded karyotype. This variability is probably due to reduced mechanical stability (John and Lewis 1968) which leads such chromosomes to non-disjunction or anaphase-lag during mitosis and meiosis. Accordingly, the $2 n=25 / 26$ individual must have originated from a $2 n=$ 26 zygote by the loss of one supernumerary in an early cell division. However, a non-disjunction of the supernumerary in a $2 n=25$ zygote can not be completely ruled out, even though, a $2 n=24$ cell line with no supernumerary has not been detected. These cells may have been eliminated in competition with $2 n=25$ and $2 n=26$ cells or they may occur in a tissue not investigated.

Two supernumerary chromosomes were seen in some metaphase II cells resulting from non-disjunction. This could represent an accumulation mechanism as described by Patton (1977) in Perognathus baileyi. This being true, individuals with more than two supernumeraries are expected to appear.

The role of supernumerary chromosomes is not clear, but some effects on morphological traits, fertility, vigor and chiasma frequency are ascribed to them (Jones 1975). Even an evolutionary significance is suggested by the wide occurrence of supernumeraries among vertebrates (Yonenaga et al. 1976). In a recent report (Assis et al. 1978), nucleolar organizing regions were described at the telomeres of both the long and short arms of a supernumerary chromosome in Akodon sp. $(2 \mathrm{n}=25)$. This finding is indicative that, at least in this species, such a chromosome has a role in nucleolar organization.

The X chromosome in Akodon sp. is polymorphic due to the presence of an enlarged short arm in some specimens. G-band analysis suggests that there is a true addition of chromosome material since the banding patterns are similar on the long arms of both $\mathrm{X}$ types.

Variations in size and morphology of the $\mathrm{X}$ chromosome in the same species are described among rodents and, in general, they are the result of an increase or 
reduction in the amount of constitutive heterochromatin visualized by C-bands (Mascarello et al. 1974, Baverstock et al. 1977). This is not the case in our specimens since the marker $\mathrm{X}$ failed to show any $\mathrm{C}$-bands either in the enlarged short arm or at the pericentromeric region. On the otherhand, a pericentromeric Cband was present in the acrocentric $X$ of this species. The short arm of the $X$ marker could be euchromatic resulting from a translocation or a duplication of a small segment, whereas, it could also be heterochromatic and not detected by $\mathrm{C}$ banding technique. Indeed, biochemical changes which affect the affinity of heterochromatin to the Giemsa staining appears to cause reduction or even the absence of C-bands (Yosida and Sagai 1975).

The X chromosome variation found in Akodon sp. is similar to that of the polymorphic autosome no. 1 of Notomus alexis (Baverstock et al. 1977). One of the chromosome forms is relatively larger than the others. This form has no short arm and shows no C-bands, while all the others show variable amounts of heterochromatin on their short arms. The origin of such a type of variation is, according to the authors, an enigma.

The male specimens with a $2 n=23 / 24$ mosaicism must have resulted from somatic elimination of the $\mathrm{Y}$ chromosome, giving rise to an $\mathrm{XO} / \mathrm{XY}$ chromosomal constitution. Meiotic analysis discarded the hypotesis of a translocation between the $\mathrm{Y}$ and an autosome since a typical sex bivalent with end-to-end pairing was observed in diplotene and metaphase I cells.

Elimination of sex chromosomes from somatic cells is found in some species of marsupials and eutherian mammals. It has been thought to represent an uncommon and extreme manifestation of the inactivation mechanism (Hayman and Martin 1965, Bianchi 1973). The elimination of the $Y$ chromosome in Akodon sp. is a sporadic event and apparently does not affect the fertility of the specimen.

\section{Summary}

In a sample of 30 specimens of Akodon sp. (Rodentia, Cricetidae), diploid numbers of $2 n=24$ and $2 n=25$ along with two mosaic cases with $2 n=25 / 26$ and $2 n=23 / 24$ were found. The inter and intraindividual chromosome variability of $2 n=24,2 n=25$ and $2 n=25 / 26$ was due to the presence of supernumerary chromosomes. The $2 n=23 / 24$ mosaic resulted from elimination of the $Y$ chromosome in somatic cells, the gonads showing a normal XY constitution. Heteromorphism of the $\mathrm{X}$ chromosome was also observed. G- and C-band patterns of mitotic and meiotic chromosomes are described.

\section{Acknowledgements}

The authors are very grateful to Dr. Luís Augusto Magalhães and Dr. Urara Kawazoe of the Universidade Estadual de Campinas and to Dr. Oscar de Souza Lopes and Mr. Emílio Dente of the Instituto Adolfo Lutz de São Paulo for providing the specimens used in this study. The authors are also indebted to Dr. Angela M. Vianna-Morgante for her critical reading of the manuscript and to Tamara June Lister for the English revision. 


\section{References}

Assis, M. F. L., Kasahara, S. and Yonenaga-Yassuda, Y. 1978. Ag-staining of nucleolus organizer regions of Akodon sp. (Cricetidae, Rodentia) with supernumerary chromosome. Mammal. Chrom. Newsl. 19: 125-126.

Baverstock, P. R., Watts, C. H. S. and Hogarth, J. T. 1977. Polymorphism of the X-chromosome, Y-chromosome and autosomes in the Australian hopping mice Notomys alexis, N. cervinus and $N$. fuscus (Rodentia, Muridae). Chromosoma 61: 243-256.

Bianchi, N. O. 1973. Consideraciones sobre los mecanismos de determinacion sexual en los mamiferos. Medicina 33: 563-570.

- and Contreras, J. R. 1967. The chromosomes of the field mouse Akodon azarae (Cricetidae, Rodentia) with special reference to sex chromosome anomalies. Cytogenetics 6: 306-313.

-, Reig, O. A., Molina, O. and Dulout, F. N. 1971. Cytogenetics of the South American Akodont Rodents (Cricetidae) I. A progress report of Argentinian and Venezuelan forms. Evolution 25: 724-736.

-, Vidal-Rioja, L. and Bianchi, M. S. 1973. Constitutive heterochromatin G-bands and Robertsonian rearrangements in the chromosomes of Akodon molinae (Rodentia-Cricetidae). Canad. J. Genet. Cytol. 15: 855-861.

-, - and - 1976. Cytogenetics of the South American Akodont rodents (Cricetidae) II. Interspecific homology of G-banding patterns. Cytologia 41 : 139-144.

Hayman, D. L. and Martin, P. G. 1965. Sex chromosome mosaicism in the marsupial genera Isoodon and Perameles. Genetics 52: 1201-1206.

John, B. and Lewis, K. R. 1968. The chromosome complement. Protoplasmatologia 6: 2-206.

Jones, R. N. 1975. B-chromosome systems in flowering plants and animal species. In: Bourne, G. H. and Danielli, J. F. eds., International Review of Cytology. New York, Academic Press p. 1 $1-85$.

Mascarello, J. T., Warner, J. W. and Baker, R. J. 1974. A chromosome banding analysis of the mechanism involved in karyological divergence of Neotoma phenax (Merrian) and Neotoma micropus (Baird). J. Mammal. 55: 831-834.

Patton, J. L. 1977. B-chromosome sytems in the pocket mouse Perognathus baileyi: meiosis and C-band studies. Chromosoma 60: 1-14.

Seabright, M. 1971. A rapid banding technique for human chromosomes. Lancet 2: 971-972.

Sumner, A. T. 1972. A simple technique for demonstrating centromeric heterochromatin. Exptl. Cell Res. 75: 304-306.

Yonenaga, Y. 1972. Chromosomal polymorphism in the rodent Akodon arviculoides ssp. $(2 \mathrm{n}=14)$ resulting from two pericentric inversions. Cytogenetics 11: 488-499.

Yonenaga-Yassuda, Y. 1979. New karyotypes and somatic and germ cell banding in Akodon arviculoides (Rodentia, Cricetidae). Cytogenet. Cell Genet. 23: 241-249.

Yonenaga, Y., Frota-Pessoa, O., Kasahara, S. and Almeida, E. J. C. 1976. Cytogenetics studies on Brazilian rodents. Ciên. e Cult. 28: 202-211.

-, Kasahara, S., Almeida, E. J. C. and Peracchi, A. 1975. Chromosomal banding patterns in Akodon arviculoides $(2 \mathrm{n}=14)$, Akodon sp. $(2 \mathrm{n}=24$ and 25$)$, and two male hybrids with 19 chromosomes. Cytogenet. Cell Genet. 15 : 388-399.

Yosida, T. H. and Sagai, T. 1975. Variation of C-bands in the chromosomes of several subspecies of Rattus rattus. Chromosoma 50: 283-300. 